\title{
Absence of antimicrobial activity of Euphorbia milii molluscicidal latex
}

\author{
Eduardo C. Oliveira-Filho',2, \\ Bianca F. G. Z. Alves' \\ Jacyara C. Lopes', \\ Valdi L. Tutunji ${ }^{3}$ \\ ${ }^{1}$ Laboratório de Ecotoxicologia, \\ Embrapa Cerrados, Planaltina (DF), \\ ${ }^{2}$ Laboratório de Microbiologia, \\ FACES, UniCEUB, Brasília (DF), \\ ${ }^{3}$ Faculdade Atenas, Paracatu (MG), \\ Brazil
}

\begin{abstract}
Introduction: Euphorbia milii latex has been used as herbal medicine and proved to be a potent plant molluscicide. Materials and Methods: The susceptibility of Staphylococcus aureus, Escherichia coli, and Pseudomonas aeruginosa to E. milii molluscicidal latex was evaluated by assays in the agar well diffusion method and tubes dilution, to determine the minimal inhibitory concentration and minimal bactericidal concentration. Results: Latex in natura (fresh) and lyophilized in a maximum viable concentration of $100 \mathrm{mg} / \mathrm{L}$ did not show any inhibitory effect on the growth of the bacterial strains tested. Conclusion: Although it has been effective as a molluscicide, this latex presented a total absence of antimicrobial activity in the two forms and concentrations tested.
\end{abstract}

Key words: Euphorbiaceae, euphorbia latex, non-target species, plant molluscicides

\section{INTRODUCTION}

The latex of the 'Crown-of-Thorns' (Euphorbia miliz) has been reported as a wart remover ${ }^{[1]}$ and an anti-inflammatory, ${ }^{[2]}$ and in China, parts of this plant, including the latex, have been used as herbal remedies for hepatitis and abdominal edema. ${ }^{[3]}$ In Brazil, the latex of E. milli was discovered to be a potent plant molluscicide and an interesting alternative to synthetic chemical products. Several studies have demonstrated its molluscicidal potency in the laboratory ${ }^{[4,5]}$ and in the field. ${ }^{[6,7]}$ The selectivity toward target aquatic snails seems to be one of the main advantages of this natural product. ${ }^{[5]}$ Studies on the chemical composition of $E$. milii have demonstrated the presence of triterpenes and flavonoids, ${ }^{\left[{ }^{[8]}\right.}$ lasiodiplodin, ${ }^{[3]}$ milliamines $A-G,{ }^{[0]}$ milliamines $\mathrm{H}$ and $\mathrm{I},{ }^{[10]}$ milliamine $\mathrm{L},{ }^{[11]}$ and euphorbin. ${ }^{[12]}$

\begin{tabular}{|l|l|}
\hline \multicolumn{2}{|c|}{ Access this article online } \\
\hline Quick Response Code: & Website: \\
\hline & www.pnrjournal.com \\
\cline { 2 - 2 } & \\
\hline
\end{tabular}

Data on the bacteriological effects of latex are scarce, and so the present study was performed to investigate its biological activity on pathogenic microorganisms, evaluating its potential antimicrobial properties.

\section{MATERIALS AND METHODS}

Euphorbia milii Desmoul. ex Boiss (syn E. splendens, Euphorbiaceae) used in the present study was identified by Dr. Ivete Maria da Silva and a voucher specimen (reference number R202859) was deposited in the herbarium of the National Museum of the Federal University of Rio de Janeiro (UFRJ). Latex was obtained from plants grown in the experimental gardens located within the FIOCRUZ campus, Rio de Janeiro, Brazil. After collection, the material was transported to laboratory and separated, in part to be tested in natura and in part to undergo a lyophilization process. Latex forms were diluted in distilled water at a maximum viable aqueous concentration of 100 $\mathrm{mg} / \mathrm{L}$. Simultaneously with the microbial tests the latex forms were tested against Biomphalaria glabrata snails to confirm their molluscicidal activity. The antimicrobial activity was evaluated by the well-diffusion agar method and the tube dilution broth test, for investigation of the minimal inhibitory concentration (MIC) and minimal

Address for correspondence:

Dr. Eduardo Cyrino Oliveira-Filho, Laboratório de Ecotoxicologia, Embrapa Cerrados, BR 020 km 18, Planaltina (DF), 73310-970, Brazil. E-mail: cyrino@cpac.embrapa.br 
bactericidal concentration (MBC). The two assays were carried out according to the method of Bauer et al. ${ }^{[13]}$ under strict adherence to CLSI, formerly known as NCCLS, criteria. ${ }^{[14]}$ In a well-diffusion agar method, wells were made in Muller-Hinton agar medium and received latex in the two different forms tested (fresh and lyophilized $-100 \mathrm{mg} / \mathrm{L}$ in distilled water). Positive control was evaluated in another plate with paper disks ( $5 \mathrm{~mm}$ in diameter) containing the antibiotic gentamicin $(10 \mu \mathrm{g})$. Both plates were inoculated with $100 \mu \mathrm{L}$ of a suspension containing $10^{8} \mathrm{CFU} / \mathrm{mL}$ of each bacteria and incubated overnight at $37^{\circ} \mathrm{C}$. The tests were performed in triplicate. After 16 hours the inhibition zones of bacterial growth around the disks and the wells were measured and recorded. In the tube dilution assay, $100 \mu \mathrm{L}$ of a suspension containing $10^{8} \mathrm{CFU} / \mathrm{mL}$ of each bacterial strain were inoculated in tubes with $10 \mathrm{~mL}$ of $100 \mathrm{mg} / \mathrm{L}$ lyophilized and fresh latex diluted in nutrient broth. The latex solutions were sterilized by filtration in $0.5 \mu \mathrm{m}$ Millipore membrane. The tubes were incubated at $37^{\circ} \mathrm{C}$ for 24 hours and visually evaluated for signs of growth. The microorganisms used were Staphylococcus aureus ATCC 25923, Escherichia coli ATCC 25902, and Pseudomonas aeruginosa ATCC 27853, and to confirm the molluscicidal activity of the latex, a 24-hour test was performed with Biomphalaria glabrata in dechlorinated water at $\mathrm{pH} 7.0-7.4$.

To calculate the 24 hour- $\mathrm{LC}_{50 \mathrm{~s}}$ for molluscicidal activity the Trimmed Spearmam Karber method was used. ${ }^{[15]}$

\section{RESULTS AND DISCUSSION}

The results showed that the positive control tubes and plate disks (gentamicin) had a clear inhibitory effect on the growth of the three bacterial strains tested. On the other hand, the tubes and plate wells with $100 \mathrm{mg} / \mathrm{L}$ of fresh and lyophilized $E$. milii latex did not show any inhibitory effect, disabling the calculations of MIC and MBC. In comparison with the previous data of latex, the molluscicidal effect was sustained with lethal concentrations to $50 \%$ of the snails in 24 hours ( 24 hours- $\mathrm{LC}_{50}$ and $95 \%$ confidence intervals) of $0.37(0.24-0.49) \mathrm{mg} / \mathrm{L}$ and $0.29(0.19-0.45)$ for fresh and lyophilized latex, respectively.

The absence of microbial inhibitory effects of Euphorbiaceae was observed in another study with E. coli. ${ }^{[16]}$ In a genotoxicity study, the latex of $E$. splendens did not present a mutagenic effect in the Ames test with Salmonella typhimurium or cytotoxicity in the Chinese hamster ovary cell assay. ${ }^{[17]}$ In an ecotoxicity evaluation of lyophilized latex by different toxicological endpoints, adverse effects were not observed on the respiratory rate of Pseudomonas putida or on the bioluminescence of the Vibrio fischeri - Microtox Test System. ${ }^{[5]}$ Although Hood et al. ${ }^{[18]}$ affirmed that the well diffusion and agar dilution methods were capable of producing inconsistent results with essential oils, in the present study, a negative result was obtained in the tube dilution method too, validating the negative data that occurred in the first one method.

Recent studies have been conducted to find microorganisms with a potential to control snails ${ }^{[19]}$, but currently plant molluscicides are still the most studied.

In conclusion, data from the present study indicate that the aqueous solution of fresh and lyophilized $E$. milii latex $(100 \mathrm{mg} / \mathrm{L})$ has no antimicrobial effect in the methods tested, showing that although latex is a potent molluscicide, it is not toxic to microorganisms. Anyway from the medical point of view, new experiments could be carried out to look for other pharmacological endpoints, as per Jyothi et al. ${ }^{[20]}$ who investigated effects on the liver and antioxidant activities of Euphorbia antiquorum.

\section{REFERENCES}

1. Hartwell JL. Plants used against cancer: A survey. Lloydia 1971;34:386-425.

2. Rao CB, Sussela K. Chemical examination of Euphorbia splendens Boj. Indian J Chem 1982;21B:495-6.

3. Lee KH, Hayashi N, Okano M, Hall IR, Wu RY, McPhail AT. Lasiodiplodin, a potent anti-leukemic macrolide from Euphorbia splendens. Phytochem 1982;2:1119-21.

4. Vasconcellos MC, Shall VT. Látex of "Coroa de Cristo" (Euphorbia splendens): An effective molluscicide. Mem Inst Oswaldo Cruz 1986;81:475-6.

5. Oliveira-Filho EC, Paumgartten FJ. Toxicity of Euphorbia milii latex and niclosamide to snails and nontarget aquatic species. Ecotoxicol Environ Saf 2000;46:342-50.

6. Mendes NM, Vasconcellos MC, Baptista DF, Rocha RS, Schall VT. Evaluation of the molluscicidal properties of Euphorbia splendens var. hislopii (N.E.B.) latex: Experimental test in an endemic area in the State of Minas Gerais, Brazil. Mem Inst Oswaldo Cruz 1997;92: $719-24$.

7. Schall VT, Vasconcellos MC, Rocha RS, Souza CP, Mendes NM. The control of the schistosome-transmitting snail Biomphalaria glabrata by the plant Molluscicide Euphorbia splendens var. hislopii (syn milli Des. Moul): A longitudinal field study in an endemic area in Brazil. Acta Trop 2001;79:165-70.

8. Pancorbo S, Hammer RH. Preliminary phytochemical investigation of Euphorbia milii. J Pharm Sci 1972;61:954-7.

9. Marston A, Hecker E. On the active principles of the Euphorbiaceae. VI Isolation and biological activities of seven milliamines from Euphorbia milii. Planta Med 1983;47:141-7.

10. Marston A, Hecker E. On the active principles of the Euphorbiaceae. VII. Milliamines $\mathrm{H}$ and I, peptide esters of 20-deoxy-5 epsilonhydroxyphorbol from Euphorbia milii. Planta Med 1984;50:319-22.

11. Zani CL, Marston A, Hamburger M, Hostettmann K. Molluscicidal milliamines from Euphorbia milii var. hislopii. Phytochem 1993;34: 89-95.

12. Dias-Baruffi M, Sakamoto M, Rosseto S, Vozari-Hampe MM. Neutrophil migration and aggregation induced by euphorbin, a lectin from the latex of Euphorbia milii, var. milii. Inflamm Res. 2000;49:732-6. 
13. Bauer AW, Kirby WM, Sherris JC, Turck M. Antibiotic susceptibility testing by a standardized single disk method. Am J Clin Pathol 1966;45:493-6.

14. Wikler MA, Low DE, Cockerill FR, Sheehan DJ, Craig WA, Tenover FC, et al. Methods for dilution antimicrobial susceptibility tests for bacteria that grow aerobically. $7^{\text {th }}$ ed. CLSI document M7-A7: Wayne/PA. 2006.

15. Hamilton MA, Russo RC, Thurston RV. Trimmed Spearman-Karber method for estimating median lethal concentrations in toxicity bioassays. Environ Sci Technol 1977;11:714-9

16. Macrae WD, Hudson JB, Towers GH. Studies on the pharmacological activity of Amazonian Euphorbiaceae. J Ethnopharmacol 1988;22:143-72.

17. Schall VT, Vasconcellos MC, Valent GU, Sato MI, Furlan EV, Sanchez PS. Evaluation of the genotoxic activity and acute toxicity of Euphorbia splendens latex, a molluscicide for the control of schistosomiasis. Braz
J Med Biol Res 1991;24:573-82.

18. Hood JR, Wilkinson JM, Cavanagh HM. Evaluation of common antibacterial screening methods utilized in essential oil research. J Essent Oil Res 2003;15:428-33.

19. Chen J, Han B, Guo S, Wang Y, He J, Zhou X, et al. Molluscicidal activity against Oncomelania hupensis of endophyte JJ18 from Pseudolarix kaempferi Gord. Phcog Res 2009;1:421-7.

20. Jyothi TM, Prabhu K, Jayachandran E, Lakshminarasu S, Setty RS. Hepatoprotective and antioxidant activity of Euphorbia antiquorum. Phcog Mag 2008;4:127-33.

How to cite this article: Oliveira-Filho EC, Alves BF, Lopes JC, Tutunji VL. Absence of antimicrobial activity of Euphorbia milii molluscicidal latex. J Pharm Negative Results 2012;3:13-5.

Source of Support: Nil. Conflict of Interest: None declared.

\section{Author Help: Online submission of the manuscripts}

Articles can be submitted online from http://www.journalonweb.com. For online submission, the articles should be prepared in two files (first page file and article file). Images should be submitted separately.

1) First Page File:

Prepare the title page, covering letter, acknowledgement etc. using a word processor program. All information related to your identity should be included here. Use text/rtt/doc/pdf files. Do not zip the files.

\section{2) Article File:}

The main text of the article, beginning with the Abstract to References (including tables) should be in this file. Do not include any information (such as acknowledgement, your names in page headers etc.) in this file. Use text/rtf/doc/pdf files. Do not zip the files. Limit the file size to $1024 \mathrm{~kb}$. Do not incorporate images in the file. If file size is large, graphs can be submitted separately as images, without their being incorporated in the article file. This will reduce the size of the file.

3) Images:

Submit good quality color images. Each image should be less than $\mathbf{4 0 9 6} \mathbf{~ k b ~ ( 4 ~ M B ) ~ i n ~ s i z e . ~ T h e ~ s i z e ~ o f ~ t h e ~ i m a g e ~ c a n ~ b e ~ r e d u c e d ~ b y ~}$ decreasing the actual height and width of the images (keep up to about 6 inches and up to about $1800 \times 1200$ pixels). JPEG is the most suitable file format. The image quality should be good enough to judge the scientific value of the image. For the purpose of printing, always retain a good quality, high resolution image. This high resolution image should be sent to the editorial office at the time of sending a revised article.

4) Legends:

Legends for the figures/images should be included at the end of the article file. 